\title{
LA SEGURIDAD CIUDADANA COMO FUNCIÓN DEL ESTADO
}

\author{
M. Josefa Ridaura Martínez
}

\begin{abstract}
SUMARIO: 1. INTRODUCCIÓN. 2. EL PROCESO DE INSTITUCIONALIZACIÓN DE LA SEGURIDAD. 3. LA ORDENACIÓN DE LA SEGURIDAD EN LA CONSTITUCIÓN ESPAÑOLA DE 1978. 3.1. Clarificación conceptual. 4. LA CONFIGURACIÓN DE LA SEGURIDAD CIUDADANA EN EL ARTÍCULO $104 \mathrm{CE}$. 5. LA SEGURIDAD CIUDADANA: FUNCIÓN DEL ESTADO. 5.1. El sentido del servicio público. 5.2. La función del Estado.
\end{abstract}

\section{INTRODUCCIÓN ${ }^{1}$}

La reciente reforma legislativa en materia de seguridad privada, así como la, hasta ahora, propuesta de reforma sobre seguridad ciudadana han generado un controvertido debate político, planteando cuestiones de máxima relevancia que afectan a uno de los temas medulares de la organización del Estado como es la garantía de la seguridad; que, sin embargo, no se corresponde cabalmente con la concepción doctrinal en esta materia, que se asienta sobre unos pilares más sólidos que los planteados en el marco de dicho debate.

Este trabajo tiene como objeto reivindicar, al calor de dicha sacudida legislativa en esta materia, la función de la Seguridad ciudadana como una función pública a desarrollar por las Fuerzas y Cuerpos de Seguridad; en tanto que exigencia constitucional, presupuesto de la salvaguarda de los derechos fundamentales y de las libertades públicas de los ciudadanos.

No obstante, esta tarea presenta importantes aristas vidriosas, derivadas de su construcción sobre conceptos polisémicos que dificultan sobremanera una construcción jurídica firme en su seno. En este sentido, nociones como Privada.

${ }^{1}$ Este estudio se enmarca en otro más amplio sobre la reciente Ley de Seguridad 
las de servicio público, seguridad pública, orden público, y la propia noción de seguridad ciudadana presentan, como consecuencia de su vasta, y no siempre bien definida utilización por los poderes públicos, elementos, aspectos o vertientes no siempre fácilmente encajables en sus tradicionales configuraciones científicas.

\section{EL PROCESO DE INSTITUCIONALIZACIÓN DE LA SEGURIDAD}

La garantía de la seguridad se ha percibido como una necesidad humana desde los orígenes de la sociedad, dotándose ya en la antigüedad fuerzas a las que se confiaba este fin. En Grecia, Platón ${ }^{2}$ proponía la división de las ciudades en tres clases: los gobernantes -que ejercerán el poder-, los guerreros y auxiliares, dirigidos por los gobernantes -encargados de defender la ciudad frente a los ataques externos y los desordenes internos-y los ciudadanos. Y, aunque no puede hablarse propiamente de una policía gubernativa, tal y como la entendemos hoy en día, si que existía, por un lado, un sistema de control social basado en la iniciativa privada, y, por otro lado, magistrados y funcionarios, que, actuando por cuenta de la polis, ejercían funciones propias de garantía de la seguridad ${ }^{3}$.

La República, en Roma, contó también con cuerpos que ejercían las funciones de policía: los ediles curules y plebeyos tenían asignadas funciones de vigilancia y mantenimiento del orden público ${ }^{4}$, ejerciendo misiones de policía urbana, y atribuyéndoseles el ius mulctae dicendi, que les facultaba para imponer multas a aquellos que alteraran el orden público ${ }^{5}$. Los ediles perdieron fuerza al llegar el Imperio, atribuyendo Augusto la función de policía a los Praefectus Urbis.

La caída del Imperio Romano dio paso al Régimen Feudal que condujo a la desmembración del poder; pues, ante la imposibilidad del monarca de defender el territorio frente a las agresiones externas, se crearon los feudos para detentarlo, contando éstos con sus propios ejércitos, sustentados por los pagos de los ciudadanos a cambio de los privilegios que los señores feudales les otorgaban. La necesidad de los monarcas de poner fin al dominio de los señores feudales, que suponía, al fin y al cabo, un peligro para tus pretensiones,

2 Platon, La República, Alianza Editorial, 2005.

3 Antolín García, M. A., La policía en Grecia de la polis al estado helenístico, Tesis Doctoral, http://eprints.ucm.es/tesis/fll/ucm-t28986.pdf (última consulta, 19 mayo 2014), 2007.

${ }^{4}$ Quienes se ocupaban de la conservación de edificios así como de la organización y control de las fiestas con el fin de evitar consecuencias desagradables, ver VIÑAS, A., Instituciones políticas y sociales en Roma: Monarquía y República, Dykinson, Madrid, 2007, p.161.

5 Torrent, A., Voz «Aediles curules», en Diccionario de Derecho Romano, Madrid, 2005, p. 90 . 
condujo a que se viera en la creación de las ciudades el debilitamiento de los feudos. Además, la formación de las ciudades medievales buscó superar los constantes problemas de seguridad a los que contribuía la dispersión de los ciudadanos; favoreciendo la concentración en núcleos urbanos, y la formación de cuerpos, sobre todo militares, para mantener la seguridad.

Con la superación de las formas políticas preestatales, el nacimiento del Estado moderno, expresado inicialmente como absoluto, condujo a una concentración del poder en manos del monarca, rompiendo la dispersión característica del orden medieval feudal. El poder del Estado se sustentó doctrinalmente en la construcción de Bodino sobre la soberanía, que le confería un poder perpetuo e ilimitado ${ }^{6}$; surgiendo, entonces, un ejercito permanente, muy distinto de las ocasionales tropas feudales. Del Leviatán, la construcción Hobbesiana del Estado absoluto ${ }^{7}$, para quien éste «es una inmensa maquina que aplasta, bajo su peso, a los hombres al precio de salvaguardar el orden ${ }^{8}$, se evolucionó hacia un despotismo ilustrado, en el que el Príncipe debía asegurar el bien y la defensa de su pueblo9. La función principal del Estado sería la garantía del orden y de la seguridad ${ }^{10}$.

La aparición del Estado implicó, organizativamente, un cambio de titularidad de los medios reales de autoridad y administración, dejando de ser de titularidad privada para convertirse en propiedad pública, primero del rey y luego del Estado ${ }^{11}$. Este fue, pues, uno de los ejes esenciales de la construcción de esta nueva estructura política: la desaparición de la privatización del poder y la atribución de su titularidad al Estado; soporte del poder, su titular abstracto y permanente, en palabras de Burdeau ${ }^{12}$. La Seguridad pasó, en consecuencia, a considerarse monopolio del Estado -soberano- ${ }^{13}$, de forma

${ }^{6}$ Bodino, J., Los Seis Libros de la República, Tecnos, Madrid, 1992.

7 T. HobBEs, al verse obligado a exiliarse debido a las circunstancias históricas, convirtió la salvaguarda de la seguridad en eje uno de los ejes centrales de su obra. El Leviatan será considerado por él como un magno artefacto que opera según leyes racionales con la misión de acabar con la inseguridad y asegurar la paz. Leviatán, Ed. Nacional, Madrid, 1979.

${ }^{8}$ Esta idea es también la sostenida, entre otros autores como por ejemplo S. PUFENDORF al considerar que el Estado se ha constituido, precisamente, para salvar la paz y la seguridad. Vid. Botella, J. y otros, El pensamiento político en sus textos, Tecnos, Madrid, 1998, pp. 185 y ss.

9 Lucas Verdu, P., Manual de Derecho Político, Tecnos, Madrid, 1987, p. 45 y ss.

${ }^{10}$ Locke, J., Ensayo sobre el Gobierno Civil, Aguilar, Madrid, 1980.

${ }^{11}$ Heller, H., Teoría del Estado, Fondo de Cultura Económica, México, 1942, p. 146.

12 Burdeau, G., Derecho Constitucional e Instituciones Políticas, Editora Nacional, Madrid, 1981, autor que llamó institucionalización del Poder al acto por el que su fundamento se transfiere de la persona de los gobernantes a una entidad: Estado, pp. 23 y 29.

13 Pero, es diferente la construcción de la soberanía de H. Grocio, que llega a entender que el poder puede ser un derecho privado del gobernante, lo cual implica la privati- 
que como expresara Max Weber éste tendría, también, el monopolio legítimo de la violencia ${ }^{14}$.

El tránsito del Antiguo Régimen a la Revolución liberal supuso el fin del poder absoluto del monarca, y con ello la sumisión del Estado al Derecho. De modo que, en el continente europeo, el origen de unas fuerzas públicas encargadas de la salvaguarda de la seguridad se puede situar en esta fase, cuando a finales del Siglo XVIII germina el Estado Constitucional tras la Revolución francesa. En efecto, el artículo 12 de la Declaración de los Derechos del Hombre y del Ciudadano de 1789 establecía que:

«La garantía de los derechos del hombre y del ciudadano necesita de una fuerza pública; por lo tanto, esta fuerza ha sido instituida en beneficio de todos, y no para el provecho particular de aquellos a quienes ha sido encomendada».

Dicho precepto ha sido objeto de diversas y antagónicas interpretaciones, al sorprender que un texto que tenía como piedra angular la garantía de los derechos, al mismo tiempo, los anudara a la existencia de una fuerza pública. Sin embargo, entendemos que el espíritu de dicho precepto era, no tanto limitar los derechos mediante la fuerza pública, sino - como se puede desprender tanto del tenor literal como contextual del mismo-afianzar la garantía de los derechos a través de una fuerza pública, en contraposición a la privada que existía en el estado de naturaleza. Esta fuerza pública, sería, así, como ha puesto de relieve Carbonell, una «consecuencia de la racionalidad que anima al Siglo de las Luces y de las tesis de Rousseau ${ }^{15}$ », reforzando su sentido contractualista, y oponiendo ideológicamente la Declaración con el Antiguo Régimen ${ }^{16}$. La Declaración de Derechos, al situar a la fuerza pública como garante de los derechos, se hacía eco, asimismo, de las ideas de Locke y de Monstesquieu ${ }^{17}$ sobre la necesidad de un pacto entre los hombres para con-

zación del poder: Del derecho de la guerra y de la paz, vid. El Pensamiento Político en sus textos, ob. cit., pp. 159-168.

14 WeBer, M., La política como profesión (traducción de Francisco Rubio Llorente), Editorial Alianza, Madrid, 1967.

${ }^{15}$ Que contó con un teórico por excelencia como Rousseau, quien considera que el hombre es bueno por naturaleza, pero que las causas de sus males son la civilización y la propiedad, por lo que será necesario realizar un contrato social, en el que el único soberano será la «voluntad general», debiendo ejercerse por todo el pueblo, siendo la ley la expresión de dicha voluntad general, orientada siempre al bien común. En su concepción, la soberanía sólo puede pertenecer al pueblo. El Contrato Social, Alianza, 1980.

16 Carbonell, M., En los orígenes del Estado Constitucional: la Declaración francesa de 1789, Instituto Iberoamericano de Derecho Constitucional, Editorial Iustitia, Perú, 2012, p. 100.

${ }_{17}$ Pero el Pacto de Locke se diferenciaba del Pacto de HobBes, púes este último entendía que el hombre, en el estado de naturaleza, era un lobo para el hombre, estando en constante guerra entre ellos, lo que justificaba el pacto. Sin embargo LocKE entendía que 
servar, con seguridad, los derechos y los bienes, y dividir el poder, estableciendo pesos y contrapesos, para limitarlo y evitar su abuso para garantizar la libertad.

La explicación en la Declaración de una fuerza pública como garantía de los derechos, y no como fuerza represiva, es la que se corresponde con los postulados del propio Estado constitucional, que aparece configurado en el mismo artículo 16 de dicha Declaración, al establecer como exigencias de la Constitución la división de poderes y el reconocimiento de los derechos; que serán la finalidad primordial del Estado de Derecho. En efecto, como literalmente expresaba dicho precepto:

«Toda sociedad en la cual no esté establecida la garantía de los derechos, ni determinada la separación de los poderes, carece de Constitución».

La salvaguarda de la vigilancia del territorio se encomendó, entonces, a cuerpos jerarquizados y disciplinados, sujetos a la jurisdicción de las autoridades políticas; aunque, su función, centrada en la obtención de información para evitar los desordenes colectivos, y su dependencia del poder político favorecieron su carácter eminentemente represivo ${ }^{18}$. Además, dicha Fuerza pública tendría un papel muy limitado, por las propias particularidades del Estado de Derecho, de cuño liberal, caracterizado por la mínima intervención estatal; un Estado abstencionista que debía limitar su actuación para preservar la libertad individual y la propiedad; y, por tanto, centrado en asegurar el orden. Los excesos en la actuación del Estado justificarán las libertades resistencia, para preservar la esfera individual y la autonomía de la voluntad frente a los poderes públicos, alcanzándose su concreción en la máxima laisser faire, laiser passer, y operándose una separación Estado-Sociedad. Su crisis dará pasó a un Estado Social en el que se le exigirá al Estado que intervenga: será un Estado intervencionista para procurar prestaciones sociales; inaugurándose, así, un nuevo constitucionalismo que supondrá la ampliación del ámbito funcional del Estado; en el que «las funciones tradicionales de regulación y policía, que comportan el ejercicio de autoridad, se complementan con la prestación de múltiples servicios ${ }^{19}$.

el hombre era bueno por naturaleza y que el pacto nacía para garantizar los derechos, separando los poderes para evitar el abuso del poder: Dos tratados sobre el Gobierno (1690). MonTesquieu, El espíritu de las leyes (1784). A su vez, estas ideas del contrato diferirán del Contrato Social de RousSEAU quien busca valores distintos como la solidaridad, la amistad, el amor familiar, entre otros, valores diferentes a la defensa de la propiedad y de los derechos individuales.

18 Anton Barbera, F. y Soler Tormo, J. I., Administración Policial. Legislación e investigación privada, Tirant lo Blanch, Valencia 2010, p. 33.

19 Sanchez Moron, M, Derecho de la Función Pública, Tecnos, Madrid, 2013, p. 33. 
El constitucionalismo posterior a la Primera Guerra Mundial y, sobre todo, a la Segunda se sustentará en la fundamentalidad de los derechos y en su ordenación como elementos vertebradores del ordenamiento constitucional. Predominarán las construcciones doctrinales sobre la naturaleza Dualista de los derechos fundamentales (formuladas primero por K. Hesse ${ }^{20}$ y seguida por su discípulo Häberle, entre otros), que predicarán la doble condición de los derechos: a) serán derechos subjetivos del ciudadano frente al Estado; y, b) también serán valores o elementos configuradores y fundamentadores del propio sistema político. Los poderes públicos, en consecuencia, estarán vinculados por el respeto y la garantía de los derechos fundamentales, que impregnarán la aplicación de todo el ordenamiento jurídico. En este contexto, las fuerzas públicas no podrán actuar más que como garantes de los derechos.

La Segunda Postguerra, además, abrirá paso al fenómeno de la internacionalización de los derechos, mediante la creación de organizaciones internacionales y regionales (Naciones Unidas y Consejo de Europa) cuyos textos introducirán unos estándares mínimos de garantía de los derechos ${ }^{21}$. Serán textos que erigirán la dignidad de la persona en un mínimo invulnerable, que, posteriormente se extenderá a las Constituciones ${ }^{22}$ que verán la luz en ese momento histórico. Este nuevo constitucionalismo influirá decisivamente en la configuración de las fuerzas de seguridad, que dejaran de concebirse como elemento de represión, y pasaran a ser, ineludiblemente, elemento de protección de los derechos.

En efecto, la Creación de Naciones Unidas forjará en la Declaración Universal de Derechos Humanos (1948) como prioridad el mantenimiento de la paz y la seguridad internacionales, así como el reconocimiento, fomento, y promoción de los derechos humanos. Particularmente, la Resolución 34/169, de 17 de diciembre de 1979, de la Asamblea General de Naciones Unidas, sobre Código de Conducta para funcionarios encargados de hacer cumplir

${ }^{20}$ Hesse, K., «Significado de los derechos fundamentales», en Manual de Derecho Constitucional, E. Benda, W. Mainofer, H. J. Vogel, K. Hesse, W. Heyde (ed.), Madrid, 1996, p. 91 y ss..

${ }^{21}$ Como subraya Paola BILANCIA «El siglo XX ha sido para el ordenamiento internacional la fase histórica de compromiso con la protección de los derechos: intentando construir una barrera que impedía su violación por parte de los Estados e, intentando salvaguardar los «estándares» mínimos, el derecho internacional ha perforado los ordenamientos nacionales para introducir la ética común o, mejor, ese patrimonio de valores comunes que constituyen la esencia de los derechos humanos». "Las nuevas fronteras de la protección multinivel de los derechos», en ReDCE, n. ${ }^{\circ} 6 / 2006$, p. 256. Vid. también CRUZ Villalon, P., «Formación y evolución de los derechos fundamentales», en Revista Española de Derecho Constitucional, núm. 25/1989, p. 35 y ss.

${ }^{22}$ Constitución de la República Italiana de 1947; Ley Fundamental de Bonn de 1949; y la Constitución Portuguesa de 1976. 
la ley, reafirma su sujeción a la protección de la dignidad humana, así como al mantenimiento y la defensa de los derechos humanos.

En el marco del Consejo de Europa cabe destacar el artículo 3 del Convenio Europeo de Derecho Humanos que establece la prohibición de la tortura o tratos inhumanos o degradantes; así como el Convenio Europeo para la prevención de la tortura y de las penas o tratos inhumanos o degradantes ${ }^{23}$, de aplicación a las personas privadas de la libertad por una autoridad pública, siendo de especial aplicación a los policías. Además, la Resolución 690 de 1979, de la Asamblea Parlamentaria del Consejo de Europa, Declaración sobre la Policía, define unas reglas deontológicas de actuación de la policía, en el marco del sistema europeo de protección de derechos. Dicha Resolución parte del papel esencial que juega la Policía en la consecución de una sociedad en paz que disfrute del orden y de la seguridad pública para el pleno ejercicio de los derechos del hombre y de las libertades fundamentales. En definitiva, dichas reglas deontológicas están orientadas a la protección de los derechos.

Todos estos instrumentos vienen a delimitar los principios y el marco de actuación de las Fuerzas de Seguridad que, en todo caso, ha de respetar y garantizar los derechos, proscribiéndose la arbitrariedad en su actuación.

\section{LA ORDENACIÓN DE LA SEGURIDAD EN LA CONSTITUCIÓN ESPAÑOLA DE 1978}

En España, la propia singularidad de nuestra agitada e inestable historia constitucional determinó el origen y la posterior evolución de las fuerzas públicas encargadas de la salvaguarda de la seguridad. Suele situarse como antecedente más directo del Cuerpo de Policía, concebida como fuerza pública, la Superintendencia General de Policía /1782), o, más concretamente, la Superintendencia General (1824); pero, lo cierto es que, la historia de las Fuerzas y Cuerpos de Seguridad en España ha debido esperar veinte siglos hasta que el texto constitucional de 1978 los ordenara como cuerpos integrados por funcionarios públicos, con la misión de garantizar los derechos fundamentales y las libertades públicas.

El artículo 104 de la Constitución regula, bajo la dependencia del Gobierno, las Fuerzas y Cuerpos de Seguridad, encomendándoles la misión de proteger el libre ejercicio de los derechos y libertades y garantizar la seguridad ciudadana.

Pero, a lo largo del articulado de la Constitución española de 1978, aparecen diversas acepciones del término «seguridad», que se refieren a categorías jurídicas distintas; por consiguiente, conviene, en primer término, reali-

${ }^{23}$ Número 126 del Consejo de Europa, hecho en Estrasburgo el 26 de noviembre de 1987. 
zar una clarificación conceptual, de modo que podamos precisar con mayor certeza la naturaleza y la ordenación de la seguridad ciudadana en el texto constitucional.

\subsection{Clarificación conceptual}

a) La Seguridad Jurídica (art. 9.3 CE)

El principio de seguridad jurídica constituye uno de los principios esenciales del Estado de Derecho. En él, este principio, como expresa Perez Luño, es un presupuesto del Derecho, «pero no de cualquier forma de legalidad positiva, sino de aquella que dimana de los derechos fundamentales, es decir, los fundamentan el entero orden constitucional»; pero, además, cumple función del Derecho que asegura la realización de las libertades. «Con ello, la seguridad jurídica no sólo se inmuniza frente al riesgo de su manipulación, sino que se convierte en un valor jurídico ineludible para el logro de los restantes valores constitucionales» ${ }^{24}$.

La proclamación del Estado de Derecho en la Constitución española de 1978 se confirma desde su Preámbulo, al revelar la voluntad de la Nación española de establecer, entre otros principios, el de seguridad. Aunque, el primer precepto en el que aparece el término «seguridad» es el art. 9.3; en el que se formula como uno de los principios constitucionales básicos de nuestro ordenamiento jurídico. Este principio, presupuesto inexcusable en un Estado de Derecho, se traduce en la suma de la certeza y la legalidad, la jerarquía y la publicidad de las normas, la irretroactividad de la norma no favorable, así como la interdicción de la arbitrariedad. Estamos así ante un principio constitucional que confiere la certeza de cómo se van aplicar las normas, excluyendo la arbitrariedad en dicha aplicación. Esta seguridad jurídica ha de ser entendida como la certeza sobre el Ordenamiento jurídico aplicable y los intereses jurídicamente tutelados; como la expectativa razonablemente fundada del ciudadano en cuál ha de ser la actuación del poder en la aplicación del Derecho; como la claridad del legislador y no la confusión normativa ${ }^{25}$.

b) El Derecho a la Seguridad personal

Por otro lado, el artículo $17 \mathrm{CE}$ regula como un derecho fundamental la seguridad personal y la libertad individual, distinguiéndose de la seguridad

${ }^{24}$ Perez Luño, A. E., «La seguridad jurídica: una garantía del derecho y la justicia», en Boletín de la Facultad de Derecho, núm. 15/2000, p. 28

${ }^{25}$ La seguridad jurídica, (art. 9.3 C.E.), es un principio general del ordenamiento jurídico y, por otra parte, un mandato dirigido a los poderes públicos pero sin configurar derecho alguno en favor de los ciudadanos (SSTC 122/1987; 126/1987 15/1986, de 31 de enero,; 36/1991, de 14 de febrero; 46/1990, de 15 de marzo; 234/2001, de 13 de diciembre, entre otras. 
jurídica en general, que garantiza el art. 9.3 de la Constitución (STC 122/1987, de 14 de julio). El contenido de ambos preceptos difiere sustantivamente: materialmente, mientras que la seguridad contemplada en el artículo 17 implica la ausencia de perturbaciones procedentes de medidas como la detención u otras similares que, «adoptadas arbitraria o ilegalmente, restringen o amenazan la libertad de toda persona de organizar en cualquier momento y lugar, dentro del territorio nacional, su vida individual y social con arreglo a sus propias opciones y convicciones». El derecho a la seguridad reconocido en el art. 17.1 de la C.E. es, así, el derecho a la seguridad personal y no a la seguridad jurídica que garantiza el art. 9.3 de la C.E. y que equivale, con fórmula obligadamente esquemática, a certeza sobre el ordenamiento jurídico aplicable y los intereses, jurídicamente tutelados ${ }^{26}$.

El derecho a la seguridad es pues, no un principio de ordenación del ordenamiento, sino un derecho fundamental, inherente al propio Estado de Derecho; que «debe entenderse en su acepción física como la libertad de la persona $\rangle^{27}$, distinguiéndose de otras acepciones de la seguridad, como la seguridad social, la seguridad pública, o la seguridad jurídica.

Además, el artículo 17 regula, no una función, como pueda ser la de la garantía de la seguridad pública, sino un derecho fundamental, objeto de recurso de amparo ante el Tribunal Constitucional.

Pero, sobre todo, los términos que pueden inducir a mayor confusión a los efectos del tema objeto de tratamiento en este estudio son los de Seguridad Pública, Seguridad Ciudadana y el de Orden Público. «Esta indistinta utilización de estos conceptos, genera una confusión no únicamente terminológica sino de efectos considerables, los cuales pueden llegar a originar la desnaturalización de lo establecido por la Constitución $»^{28}$. Por ello, conviene detenerse en su delimitación.

\section{c) Orden público: (arts. 16.1 y $21.2 \mathrm{CE}$ )}

En el Anteproyecto de Constitución se atribuía a las Fuerzas del Orden Público, bajo la dependencia del Gobierno, la misión de defender el ordenamiento constitucional, proteger el libre ejercicio de los derechos y libertades y garantizar la seguridad ciudadana ${ }^{29}$. Pero, fue la Ponencia constitucional la que cambio el nombre de Fuerzas de Orden Público por el de Fuerzas y Cuer-

${ }^{26}$ SSTC 15/1986, de 31 de enero de 1986, FJ 2; 15/1986, de 31 de enero de 1986. Vid. García Morillo, J.: El derecho a la libertad personal, Tirant lo Blanch, Valencia, 1995.

27 Serra CRIStobal, R.: «El reconocimiento del derecho a la libertad y a la seguridad en el Tratado Constitucional de la Unión Europea», en CARRILlo, M. y LoPEZ BofILl, H., La Constitución Europea, Tirant lo Blanch, Valencia, 2006, p. 556

${ }^{28}$ FreiXes San Juan, T. y Remotti Carbonell, J.C: «La configuración constitucional de la seguridad ciudadana», Revista de Estudios Políticos, núm. 87, 1995, p. 144.

${ }^{29}$ BOC, de 5 de enero de 1978. 
pos de Seguridad ${ }^{30}$. La razón de este cambio operado por nuestro texto constitucional no fue casual, sino que el abandono del término orden público para definir la misión de los Cuerpos de Policía fue plenamente deliberado ${ }^{31}$, consecuencia de las connotaciones peyorativas que éste había tenido en la reciente historia española.

Para entender el rechazo tan enérgico que genera el término orden público en nuestro ordenamiento -calificado por Martín Retortillo como una «expresión odiosa $»^{32}$ parece conveniente que nos detengamos, al menos sucintamente, en la evolución que éste ha ido experimentando a lo largo de nuestra historia constitucional.

En la Constitución de $1812^{33}$ ya se utilizó el término orden público, y, con posterioridad, también lo hicieron los textos constitucionales de 1837, 1845, 1869 y 1876; en todos ellos se hablaba de preservación del orden interior. Pero, la ampliación del concepto de orden público se produjo por medio de la legislación de desarrollo: la primera La Ley de Orden Público de 23 de abril de 1870 sólo admitía su aplicación en caso de graves desórdenes que dieran lugar a la suspensión de las garantías cuando así lo exigiera la seguridad del Estado en circunstancias extraordinarias ${ }^{34}$; sin embargo, los textos que le siguieron fueron ampliando, progresivamente, dicho contenido. En este sentido, la Ley de 1933 amplió extensamente las facultades del Gobierno para la defensa del orden público, así como los supuestos en los que éste podía entenderse perturbado. Pero, fue la Ley de 30 de julio de 1959, la que lo amplió desmedidamente conteniendo un listado inusitado de actos contrarios al mismo. El texto se expresaba en los siguientes términos:

«El normal funcionamiento de las Instituciones públicas y privadas, el mantenimiento de la paz interior y el libre y pacífico ejercicio de los dere-

${ }^{30}$ BOC, de 17 de abril de 1978, manteniéndose dicha formulación en los trámites sucesivos.

${ }^{31}$ Chinchilla Marin, C.: Legislación sobre Fuerzas y Cuerpos de Seguridad, Tecnos, Madrid, 1986.

${ }^{32}$ Martin Retortillo, L.: «El orden público como límite al derecho de libertad religiosa», Bajo el signo de la Constitución, Instituto de Estudios de Administración Local, Madrid, 1983, p. 298.

${ }^{33}$ Art. 170: «La potestad hacer ejecutar las leyes reside exclusivamente en el Rey, y su autoridad se extiende a todo cuanto conduce a la conservación del orden público en lo interior, y a la seguridad del Estado en lo exterior». Pero, la Constitución atribuía el mantenimiento del orden público al Ejercito, produciéndose una injerencia militar en la vida civil, vid. IGLESIAS MACHADO, S., «La evolución del concepto de orden público a través de las Constituciones españolas hasta 1812», en Revista de Derecho Uned, núm. 7/2010, p. 393.

${ }^{34}$ Un estudio más amplio de esta evolución puede verse en Izu BELloso, M.J., «Los conceptos de orden público y seguridad ciudadana tras la Constitución de 1978», en REDA 58/1988, especialmente las páginas 7 y ss. 
chos individuales politicos y sociales, reconocidos en las Leyes constituyen el fundamento del orden público» (art. 1).

Por su parte, el artículo 2 se refería al enunciado de los supuestos que podían entenderse contrarios al orden público de modo muy amplio y abierto; aunque su aplicación práctica todavía lo fue mucho más, llegándose a aplicar de modo represivo.

En consecuencia, los excesos en la interpretación y aplicación práctica del concepto de orden público por parte de las autoridades gubernativas, identificándose éste con autoritarismo y represión policial, provocaron el rechazo de los constituyentes del 78, desterrándolo deliberadamente del artículo 104 del texto constitucional. Ni la LO 1/1992, de 21 de febrero, sobre Protección de la Seguridad Ciudadana, ni la Ley Orgánica 2/1986, de 13 de marzo, de Fuerzas y Cuerpos de Seguridad, siguiendo la estela constitucional, utilizaron el término orden público como habilitador de sus competencias. Pese a ello, en el marco del Derecho Público, nuestro ordenamiento está plagado de referencias constantes al mismo, véase por ejemplo, la Ley de Extranjería cuando se refiere a la expulsión de extranjeros por amenazas al orden público (Artículos 57 y 58). Pero, sorprende más que sean los Estatutos de algunos Autonomía los que recurren a dicha noción; es el caso del Estatuto Catalán en el artículo 164. 5.a) que al regular las competencias de la Generalitat en materia de Seguridad Pública atribuye las funciones propias de seguridad ciudadana y el orden público a la Policía de la Generalitat-Mossos d'Esquadra. También el artículo 17 del Estatuto Vasco reserva la competencia de la Policía Autónoma a para la protección de las personas y bienes y el mantenimiento del orden público dentro del territorio autónomo.

Ciertamente, el concepto de orden público no es exclusivo del ordenamiento español, por lo que la aplicación excesiva que se hizo del mismo en el régimen anterior no puede hacerse extensiva a todo ordenamiento comparado, yendo su manejo ligado a las circunstancias históricas y políticas de cada Estado; en consecuencia, conceptualmente, no puede identificarse el orden público con una aplicación determinada del mismo. De hecho, la doctrina administrativista ha tratado en profundidad este concepto, ofreciéndonos valiosos estudios sobre su conceptuación y evolución.

En primer lugar, de la diversas nociones existentes de orden público, conviene precisar que la consideración del orden público como misión encomendada a las Fuerzas públicas es un concepto que, como indica Berriatua ${ }^{35}$, entra en la esfera del Derecho Público, escapando del orden público contemplado, por ejemplo, en el artículo 6.2 del Código Civil, que se refiere a él como límite para la inaplicación de la ley y de la renuncia de los derechos en ella contenidos.

35 Berriatua San Sebastian, J., «Aproximación al concepto de seguridad ciudadana», en Revista Vasca de Administración Pública, núm. 41/1995, p. 379. 
En segundo lugar, cabe destacar, principalmente, $\operatorname{dos}^{36}$ formulaciones divergentes de este concepto: en primer lugar, la noción metajurídica en la que se identifica el orden público como «buen orden de la comunidad» (Otto Mayer), que al no estar positivizado conduce a un planteamiento sociológico del mismo; concepción seguida también por Virga en Italia, quien no identifica el orden público con el Ordenamiento jurídico, sino con la tutela de bienes y principios esenciales para una convivencia civil, pero que no estén tomados en consideración por una norma jurídica ${ }^{37}$. En segundo lugar, y en contraposición a la anterior, se ha mantenido la concepción del orden público como orden jurídico, establecido por el Derecho para garantizar la libertad del ciudadano (Ranelletti). Pero, aún así, estamos ante un concepto indeterminado, que requiere su concreción ${ }^{38}$, debiendo entenderse en un sentido estricto como orden necesario para el ejercicio de los derechos fundamentales y de las libertades públicas.

Nuestro texto constitucional de 1978 no entiende el orden público como la misión de las Fuerzas y Cuerpos de Seguridad, sino como un límite al ejercicio de ciertos derechos fundamentales; ya no aparece, pues, «como una cláusula general habilitadora de poderes indeterminados a favor de las autoridades administrativas» ${ }^{39}$. En concreto, dos son los preceptos constitucionales en los que podemos encontrar la expresión «orden público»: por un lado, el artículo 16.1 que lo establece como límite a la manifestación de la libertad ideológica, religiosa y de culto; por otro lado, el artículo 21.2 al referirse a los límites del derecho de reunión en lugares de tránsito público y manifestación. Estos preceptos no descartan la opción del constituyente por una concepción metajurídica del orden público, ya que lo está circunscribiendo al orden público protegido por la ley. Ahora bien, dicha ley, ineludiblemente, ha de cumplir con los parámetros constitucionales de respeto a los derechos fundamentales y las libertades públicas.

Con acierto, la consideración de orden público como límite implícito, con carácter general, de los derechos fundamentales ha sido criticada por $\mathrm{Carro}^{40}$; pues la mención expresa en los artículos 16 y $21 \mathrm{CE}$ del orden público descarta toda interpretación del mismo con carácter amplio. En efecto, «cual-

${ }^{36}$ Tema abordado en profundidad por CARro Fernandez-VAlmayor, J.L., «Sobre los conceptos de orden público, seguridad ciudadana y seguridad pública», en Revista Vasca de Administración Pública, núm. 27/1990, p. 9 y ss.

37 VIRGA, P., La potestá di policía, Giuffré, Milano,1954, p. 19 y ss.

${ }^{38}$ Defendido en España por autores como De La Morena De La Morena y De LA MorenA, L., «Los conceptos de «orden público» y de «seguridad ciudadana» en la reciente Ley Orgánica 2/1986, de 13 de marzo, de Fuerzas y Cuerpos de Seguridad y su incidencia sobre policías autonómicas y municipal», en $R E A L$ 234/1978, pp. 289313

${ }^{39}$ IzU Belloso, M.J., «Los conceptos de orden público y seguridad ciudadana tras la Constitución de 1978», ob. cit. p. 11.

${ }^{40}$ ob. cit. p. 21 
quier interpretación de la misma conducente a su configuración como cláusula general habilitadora de intervenciones administrativas limitadoras o restrictivas del ejercicio de los derechos constitucionales reconocidos resulta contraria a los mandatos constitucionales» ${ }^{41}$. La consideración del orden público como límite expreso al ejercicio de estos derechos fundamentales sólo admite una interpretación restrictiva, acorde con el principio favor libertatis; ya que toda limitación a un derecho fundamental ha de cumplir unas exigencias $^{42}$, remarcadas por Tribunal Constitucional:

En relación con el derecho de reunión el Tribunal reafirma que su limitación requiere una motivación específica; por lo que han de aportarse las razones que llevan a la autoridad gubernativa a concluir que el ejercicio del derecho producirá una alteración del orden público...» ${ }^{43}$.

La misma interpretación restrictiva cabe hacer respecto al artículo 16 de la Constitución, ya que el artículo 3.1 de la Ley Orgánica 7/1980, de Libertad Religiosa, es más explícito a la hora de establecer los elementos constitutivos del orden público protegido por la Ley en el ámbito de una sociedad democrática, como límites a la libertad religiosa y de culto: la salvaguardia de la seguridad, de la salud y de la moralidad pública. Es cierto, que, pese a esta referencia a los elementos que integran el orden público, nos encontramos, claramente, ante concepto jurídicos indeterminados. Pero, de la interpretación del Tribunal Constitucional se infiere que la limitación del derecho por alteración del orden público ha de ser de tal magnitud que ponga en peligro la inte-

${ }^{41}$ Freixes San Juan, T. y Remotti Carbonell, J.C., «La configuración constitucional de la seguridad ciudadana», Revista de Estudios Políticos, núm. 87/1995, pp. 148-149

${ }^{42}$ a) Deben contenerse en una norma con rango de ley que debe fijar de manera expresa, precisa, cierta y previsible el límite en cuestión. No caben delegaciones en materia de límites a los derechos fundamentales: el legislador no puede habilitar a otros poderes públicos para fijar los límites. (STC 292/2000); b) La «exigencia de que los límites de los derechos fundamentales hayan de ser interpretados con criterio restrictivo y en el sentido más favorable a la eficacia y a la esencia de tales derechos» (SSTC 159/86, 254/88). c) Asimismo, se desprende la necesidad de que toda restricción de los derechos deba estar justificada (STC 62/82, de 15 de octubre). d) Las limitaciones que se establezcan no pueden obstruir el derecho más allá de lo razonable (SSTC 53/1986, de 5 de mayo, 120/1990). e) Todo acto o resolución que limite derechos fundamentales ha de asegurar que las medidas limitadoras sean necesarias para conseguir el fin perseguido (SSTC 62/1982; 13/1985). f) Ha de atender a la proporcionalidad entre el sacrificio del derecho y la situación en que se halla aquel a quien se impone (SSTC 37/89; 120/1990). g) Toda limitación de un derecho ha de respetar, en todo caso, su contenido esencial, no puede desvirtuar el derecho en sí (STC 11/1981). Si el límite al derecho fundamental afecta a su contenido esencial, en realidad no se está limitando el derecho, sino suprimiéndolo o privando a su titular de su disfrute.

43 Entre otras, vid las Sentencias del Tribunal Constitucional 193/2011, de 12 de diciembre; 195/2003, de 27 de octubre; 96/2010, de 15 de noviembre; 301/2006, de 23 de octubre. 
gridad de las personas o de los bienes o suponer un sacrificio desproporcionado de otros bienes y valores constitucionalmente protegibles ${ }^{44}$. Sólo razones convincentes e imperativas pueden justificar las restricciones de la libertad ${ }^{45}$.

En síntesis, el Alto Órgano, en relación con el concepto de orden público, ha ido perfilando su conceptuación hasta llegar a considerar que un componente esencial de dicho concepto lo constituye la garantía de los derechos fundamentales y de las libertades públicas ${ }^{46}$. Esta interpretación es, pues, la que se sostiene por la mayoría de la doctrina, ya que es la única que se puede sostener en un ordenamiento constitucional que gira sobre la fundamentalidad de los derechos, vinculando a todos, especialmente, a los poderes públicos, y los convierte en clave de bóveda de todo el edificio constitucional.

En consecuencia, que el constituyente descartara deliberadamente identificar la defensa de la seguridad y la salvaguarda del orden público, y concibiera a este último como un límite al ejercicio de determinados derechos, reafirma la tajante separación de la ordenación constitucional de ambos términos; de modo que no puede identificarse, al menos constitucionalmente, la función de las Fuerzas y Cuerpos de Seguridad con la preservación del orden público concebido como cláusula habilitadora de la vis expansiva de la función de éstas.

\section{d) Seguridad pública}

La Constitución de 1978 establece en el artículo 149.1. 29 la competencia exclusiva del Estado en materia de «Seguridad pública, sin perjuicio de la posibilidad de creación de policías por las Comunidades Autónomas en la forma que se establezca en los respectivos Estatutos en el marco de lo que disponga una ley orgánica».

En principio, de la lectura del precepto y de su ubicación, podría desprenderse que el constituyente está refiriéndose al término seguridad pública como un criterio delimitador de competencias entre el Estado y las Comunidades Autónomas. Sin embargo, la competencia se delimita sobre una materia, y ésta ha de tener un contenido sustancial claro, para saber concretamente sobre que esfera puede actuarse; por ello, parece difícil que puede entenderse el término seguridad pública como un criterio, exclusivamente, de delimitación competencial. Sentado, pues, que la competencia en materia de seguridad gira sobre

${ }^{44}$ STC 193/2011: «solamente si la reiteración en el ejercicio del derecho fundamental provoca estos problemas de orden público, como puede suceder si se pretende la ocupación indefinida o excesivamente prolongada en el tiempo de un espacio de una manera que se ponga[n] en peligro los bienes y derechos que a las autoridades corresponde proteger, es admisible la medida de la prohibición, como se admitió en el caso examinado en la STC 66/1995, de 8 de mayo» (SSTC 284/2005, de 7 de noviembre, FJ 6 y 301/2006, de 23 de octubre, FJ 4)

45 STC 96/2010, de 15 de noviembre.

46 STC 19/1985, de 13 de febrero. 
un contenido determinado que es necesario clarificar, varias precisiones cabe hacer al respecto: en primer lugar, en relación con la delimitación del contenido de la seguridad pública, ésta ha sido concebida como un bien constitucionalmente protegido cuyo objeto es «tanto la adopción de medidas preventivas ante peligros o riesgos calamitosos como la garantía de funcionamiento y eficacia de los entes y órganos públicos, la protección de los bienes públicos y el aseguramiento del cumplimiento de los deberes y obligaciones jurídicos, ya sea con medidas preventivas o de mantenimiento o de restablecimiento» ${ }^{47}$.

Si bien es cierto que materialmente, la seguridad pública tiene como objeto la protección de personas y bienes y el mantenimiento de la tranquilidad y el orden ciudadano; entendemos que dicho concepto se define también por el ejercicio de las competencias, a través de una doble vertiente: a) verticalmente, en atención a la competencia que el artículo 149.1.29 reserva al Estado en exclusiva. b) horizontalmente, en atención a los órganos competentes para garantizar dicha seguridad.

\section{a) La seguridad pública como criterio delimitador de competencias}

En primer lugar, el propio Tribunal concibe la seguridad pública como concepto delimitador de la competencia de los poderes públicos. Por un lado, al delimitar competencias en materia de seguridad, aborda la diferencia entre orden público y seguridad pública como criterio delimitador de competencias entre Estado y Comunidades Autónomas, pero lo hace de forma poco satisfactoria. En efecto, en sus primeras Sentencias el Tribunal ${ }^{48}$ partía de que el concepto de seguridad pública es una noción más precisa que la de orden público, al centrarse la primera en la actividad dirigida a la protección de personas y bienes, y al mantenimiento de la tranquilidad $\mathrm{u}$ orden ciudadano; mientras que el orden público incluye cuestiones, por ejemplo, como la salubridad, y, por tanto, es más amplio. Como puede advertirse, el Tribunal Constitucional está refiriéndose a un concepto de orden público que queda lejos del que nos hemos referido anteriormente como límite al ejercicio de determinados derechos fundamentales. El origen de esta imprecisión terminológica creo que está en el hecho de que en el caso que resuelve la Sentencia a la que nos estamos refiriendo dirime un conflicto de competencias entre el Estado y Cataluña ${ }^{49}$, cuyo Estatuto, como hemos podido apreciar con anterioridad, emplea el término orden público como competencia de Generalitat.

${ }^{47}$ Freixes San Juan, T. y Remotti Carbonell, J.C.: «La configuración constitucional de la seguridad ciudadana», en Revista de Estudios Políticos, núm. 87/1995, p. 153

48 STC 33/1982, de 8 de junio.

49 Promovido por la Generalidad de Cataluña frente a la comunicación dirigida por el Gobernador civil de Barcelona al Consejero de Sanidad, y Seguridad Social de la Generalidad de 21 de septiembre de 1981, haciéndole saber la adopción de medidas en relación con determinadas partidas de mejillones en estado nocivo. 
Por otro lado, escapa de nuestro objeto adentrarnos en la determinación competencial entre Estado y $\mathrm{CCAA}^{50}$ en este campo, pues nuestro propósito se centra en clarificar conceptualmente la noción de seguridad en el ordenamiento constitucional; sin embargo, si que conviene aclarar que, si bien el concepto de seguridad ciudadana admite dos vertientes, una más amplía, a la que nos referiremos más tarde, y otra más estricta, el Tribunal Constitucional a la hora de delimitar competencias, opta por ceñir la estatal a la noción más estricta de seguridad pública ${ }^{51}$, admitiendo que también las CCAA puedan asumirlas en materia de seguridad pública, cuando afirma que para ello la necesidad de que esa $<$ Comunidad Autónoma haya asumido en su Estatuto de Autonomía competencias en materia de protección de personas y bienes y de mantenimiento del orden público; es decir, en materia de «seguridad pública» $>{ }^{52}$. Además, cuando confluyan otros títulos competenciales de la CCAA («espectáculos» y «policía autónoma»), su incidencia ha de ser valorada para que la invocación por el Estado de la «seguridad pública» no genere, sin mayor consideración, el desapoderamiento competencial de la $\mathrm{CCAA}^{53}$.

\section{b) Contenido material}

En un sentido amplio, la seguridad pública tiene como finalidad la protección de personas y bienes y el mantenimiento de la tranquilidad y el orden ciudadano, incluyendo según el propio Tribunal Constitucional, «un conjunto plural y diversificado de actuaciones, distintas por su naturaleza y contenido, aunque orientadas a una misma finalidad tuitiva de dicho bien jurídico». Desde esta perspectiva, la noción de seguridad pública puede ir más allá de

${ }^{50}$ Diversas son las CCAA que han previsto estatutariamente competencias en este orden: Andalucía: L.O. 2/2007, de 19 de marzo, de reforma del Estatuto de Autonomía para Andalucía (Artículo 65. Policía autonómica); Aragon: L.O. 5/2007, de 20 de abril, de reforma del Estatuto de Autonomía de Aragón (Artículo 76. Policía autonómica). Castilla y León: L.O. 14/2007, de 30 de noviembre, de reforma del Estatuto de Autonomía de Castilla y León (Artículo 72 Competencias sobre seguridad pública. Cuerpo de Policía de Castilla y León). Cataluña L.O. 6/2006, de 19 de julio, de reforma del Estatuto de Autonomía de Cataluña (Artículo 164. Seguridad pública.); Comunitat Valenciana L.O.1/2006, de 10 de abril, de reforma de la L.O.5/1982, de 1 de julio, de Estatuto de Autonomía de la Comunidad Valenciana (Artículos 49 y Artículo 55). Illes Balears L.O. 1/2007, de 28 de febrero, de reforma del Estatuto de Autonomía de las Illes Balears (Artículos 30, Artículo 33 Policía de las Illes Balears). L.O. 7/2010, de 27 de octubre, de reforma de la L.O. 13/1982, de 10 de agosto, de reintegración y amejoramiento del Régimen Foral de Navarra.; País Vasco: Ley Orgánica 3/1979, de 18 de diciembre, de Estatuto de Autonomía para el País Vasco (art. 17).

${ }^{51}$ STC 117/1984, de 5 de diciembre.

52 STC 172/2013, de 10 de octubre.

${ }^{53}$ SSTC 104/1989, de 8 de junio; 52/1993, de 11 de febrero, 313/1994, de 24 de noviembre. 
la regulación de las intervenciones de la «policía de seguridad», es decir, de las funciones propias de las Fuerzas y Cuerpos de Seguridad; de modo que esas actividades policiales no agotan el ámbito material de lo que hay que entender por seguridad pública ${ }^{54}$.

Un ejemplo de esta concepción amplia es el art. 6.4 del Real Decreto 1997/1995, de 7 de diciembre, por el que se establece medidas para contribuir a garantizar la biodiversidad mediante la conservación de los hábitats naturales y de la fauna y flora silvestres, en la que se exige que concurran para considerar autorizable el proyecto «consideraciones relacionadas con la salud humana y la seguridad pública». Otros aspectos y otras funciones distintas de los Cuerpos y Fuerzas de Seguridad, y atribuidas a otros órganos y autoridades administrativas que integran el concepto de seguridad pública lo constituyen la «protección civil»» ${ }^{55}$, que requiere para la consecución de sus fines la integración y movilización de recursos humanos muy heterogéneos y no sólo policiales; o la custodia, traslado y eventualmente destrucción de determinados productos estupefacientes y psicotropos se incardinan en las materias «seguridad pública» y administración de justicia, entre otros. ${ }^{56}$

En definitiva, la Seguridad Publica, es un concepto amplio que no se ciñe, sólo, a la actuación de las Fuerzas y Cuerpos de Seguridad; siendo ésta sólo una parte de la más amplia de seguridad pública; aspectos que trascienden de la mera actuación policial.

Esta noción de seguridad pública la comparte Ballbé quien entiende que, frente al concepto más ideologizado de orden público, la seguridad pública está en íntima relación con el cumplimiento de la ley, concibiéndose en un Estado democrático como la "protección de los bienes jurídicos colectivos y la vigilancia frente a los peligros que acechan a esos bienes», no ciñéndose dichos peligros a los desordenes en la calle, sino que abarcan también «las amenazas contra la salud, contra el medio ambiente, y, en definitiva, todas las actividades que puedan acarrear un daño grave e incluso irreversible para un sector de la sociedad, ya sea en materia de utilización de la energía nuclear, del transporte o de la producción alimentaria, entre otras» ${ }^{57}$.

${ }^{54}$ SSTC 33/1982, de 8 de junio, FJ 3; 104/1989, de 8 de junio, FJ 3; 235/2001, de 13 de diciembre, FJ 8; y 154/2005, de 9 de junio, FJ 5). 235/2001, FJ. 6; 172/2013, de 10 de octubre. SSTC 148/2000, de 104/1989, de 8 de junio, FJ 3, 33/1982, de 8 de junio, $117 / 1984$, de 5 de diciembre, 123/1984, de 18 de diciembre, y 59/1985, de 6 de mayo),

55 SSTC 25/2005, de 26 de febrero, FJ 6; 155/2013, de 10 de septiembre

56 SSTC 104/1989, de 8 de junio; 123/1984, de 18 de diciembre; 133/1990, de 19 de julio; 54/1990, de 28 de marzo. Vid. más detalladamente, RuBio LlorenTE, F., «Tribunal Constitucional y seguridad ciudadana», en http:/www.uned.es/facdere/duque_ahumada/14/ponencias_XIV_seminario/8_Ponencia \%20Fran cisco\%20Rubio\%20Llorente.pdf (última consulta, 12 mayo 2014)

57 Ballbé Mallol, M.: «Diez años de seguridad y política autonómicas», en Autonomies: Revista catalana de derecho público, núm. 12/1990, pp-116-117. 
e) Seguridad ciudadana

Nuestro texto constitucional encomienda en el art. 104 a las Fuerzas y Cuerpos de Seguridad, bajo la dependencia del Gobierno, la misión de proteger el libre ejercicio de los derechos y libertades y garantizar la seguridad ciudadana.

Al igual que los conceptos que hemos abordado hasta el momento, el de seguridad ciudadana es, también, "proteico y equívoco» ${ }^{58}$, ofreciéndose del mismo por parte de la doctrina científica diversas conceptuaciones: omnicomprensivo de la actividad policial frente a todo tipo de peligros ${ }^{59}$. Protección de las personas y bienes frente a acciones violentas o agresiones, situaciones de peligro o calamidades públicas, distinguiéndose del orden público, (entendido como protección del libre ejercicio de los derechos fundamentales) ${ }^{60}$.

Frente a estas posiciones que, de una forma u otra, identifican la seguridad ciudadana con la actuación policial, algunos autores ${ }^{61}$ entienden que existe una identificación entre seguridad ciudadana o pública, por lo que vienen a ser sinónimas, al entender que la Constitución emplea ambas en los artículos 104 y 149 con el mismo sentido, refiriéndose a la actividad de los Cuerpos de Policía.

Nosotros compartimos la posición doctrinal que $\mathrm{e}^{62}$ entiende que el concepto de seguridad ciudadana sólo coincide en parte con el de seguridad pública. En efecto, como hemos podido comprobar, la seguridad pública es un concepto amplio que abarca no sólo la seguridad en la calle, sino que incluye peligros o amenazas contra el medio ambiente, o la salud pública; mientras

${ }^{58}$ Como ha puesto de relieve De La Morena De La Morena y De La Morena, L., «Los conceptos de 'orden público' y de 'seguridad ciudadana'», ob. cit., p. 31

59 AgirReazkuenaga, I., «La coacción administrativa directa», Cívitas-Instituto Vasco de Administración Pública, Madrid, 1990, p. 366.

${ }^{60}$ Carro Fernandez-Valmayor, J.L., «Sobre los conceptos de orden público, seguridad ciudadana y seguridad público», en Revista Vasca de Administración Pública, núm. 27/1990. Conceptuación compartida por FernANDEZ SEGADO, F., «Comentario al Artículo 104», en Comentarios a la Constitución, Alzaga VillaAmil, O. (dir.), tomo VIII, Edersa, Madrid, p ob. cit. p. 508.

${ }^{61}$ IzU Belloso, M.J., «Los conceptos de orden público y seguridad ciudadana tras la Constitución de 1978», en REDA 58/1988, pp. 244, 245 y 252.

${ }^{62}$ Barcelona Llop, J., «Comentario al Artículo 104», en Comentarios a la Constitución española, coord. por Mercedes Pérez Manzano, M., Borrajo Iniesta, I.; María Emilia Casas Baamonde, $\mathrm{M}^{\mathrm{a}}$. E (dir.), Miguel Rodríguez-Piñero y Bravo-Ferrer, M. (dir.), Fundación Wolters Kluwer, Madrid, 2006, p. 1704. El autor considera que «frente a la amplitud de la seguridad pública, el de seguridad ciudadana «ha de entenderse en el sentido de situación de apacibilidad que permite a las personas el pacífico y sosegado ejercicio de su autonomía individual dentro del marco dispuesto por la ley... es un concepto que está muy próximo a la idea de tranquilidad en las calles o, si se quiere, a la ausencia de perturbaciones materiales que incomoden o dificulten el discurrir ordinario de la vida de la gente». 
que la noción de seguridad ciudadana que utiliza el artículo 104 de la Constitución abarca las medidas de actuación policial, tanto de prevención como de reparación, que tienen como finalidad garantizar el desarrollo libre de la convivencia y del ejercicio de los derechos fundamentales.

\section{LA CONFIGURACIÓN DE LA SEGURIDAD CIUDADANA EN EL ARTÍCULO 104 CE}

Como hemos visto, de acuerdo con el artículo 104 del texto constitucional, la garantía de la seguridad ciudadana corresponde a las Fuerzas y Cuerpos de Seguridad, dependientes del Gobierno, a quien el artículo 97 le encomienda las funciones de dirección política y potestad reglamentaria sobre la seguridad ciudadana.

De la ubicación del precepto, así como de su contenido, cabe extraer una serie de consideraciones: en primer lugar, la inclusión de las Fuerzas y Cuerpos de Seguridad en el Título IV confirma su naturaleza civil; diferenciándose de las Fuerzas Armadas (constituidas por el Ejército de Tierra, la Armada y el Ejército del Aire), que están reguladas en el título Preliminar (artículo 8), siendo su naturaleza militar. Además, su diferencia también es funcional, puesto que la misión constitucionalmente atribuida al Ejercito es garantizar la soberanía e independencia de España, y defender su integridad territorial y el ordenamiento constitucional; mientras que la de las Fuerzas y Cuerpos de Seguridad es la de proteger el libre ejercicio de los derechos y libertades y garantizar la seguridad ciudadana.

En segundo lugar, el cambio terminológico operado en el texto constitucional no es casual: de Fuerzas del Orden Público, se pasa a hablar de Fuerzas y Cuerpos de Seguridad; y es que, como hemos podido verificar, no se trata sólo de un simple cambio semántico, sino que el uso consciente de la terminología del texto constitucional implica cambios sustanciales en la ordenación constitucional de las Fuerzas y Cuerpos de Seguridad. En efecto, la garantía de la seguridad va ligada a la protección del libre ejercicio de los derechos y libertades; de tal forma que esta configuración constitucional sujeta a los órganos encargados de velar por la seguridad a los mandatos constitucionales; estando vinculados directamente por los derechos fundamentales y las libertades públicas. Así lo confirma el Tribunal Constitucional cuando avala que esta ordenación constitucional persigue asegurar la adaptación del sistema policial, de sus funciones y de sus principios básicos de actuación al orden constitucional; y por tanto, articula la función de las Fuerzas y Cuerpos de Seguridad al servicio de la comunidad para garantizar al ciudadano el libre y pacífico ejercicio de los derechos que la Constitución y la Ley les reconocen. De forma que, cualquier otra configuración de las Fuerzas y Cuerpos de Seguridad colisionaría con el orden constitucional democrático, que es «incompatible con el uso de métodos represivos ilegítimos» (STC 55/ 
1990, de 28 de marzo). En consecuencia, nuestro ordenamiento constitucional no admite cualquier configuración de las Fuerzas y Cuerpos de Seguridad; sólo la que sujeta el ejercicio de estas funciones a unas garantías de respeto a los derechos fundamentales.

En tercer lugar, la ubicación del artículo 104 en el Título dedicado al Gobierno y a la Administración tiene unas connotaciones determinadas, ya que, como resalta Fernández Segado, los Cuerpos policiales encuentran su «razón de ser en las misiones que la Constitución les atribuye» ${ }^{63}$.

\section{LA SEGURIDAD CIUDADANA: FUNCIÓN DEL ESTADO}

De la ordenación constitucional de la seguridad ciudadana que hemos visto, desde nuestro punto de vista, resulta, ineludiblemente, la comprensión de la misma como una función propia del Estado, lo que determina la exclusividad de su garantía por los poderes públicos. En efecto, la construcción de este trabajo la hemos articulado sobre un eje vertebrador: la existencia del Estado, tal y como se justifica desde sus orígenes, entraña la asunción de funciones que sólo él puede desempeñar, pues se trata de funciones que comportan ejercicio de autoridad; estamos, así, ante las funciones que se atribuyen al Estado en función de su poder de imperio y que sólo él puede desarrollar para garantizar su efectividad: Seguridad, Justicia, Defensa, Moneda.

Pero, es habitual utilizar la expresión «servicio público» ${ }^{64}$ para referirse a las funciones que sólo al Estado le corresponde desempeñar (como ente abstracto; no me refiero aquí a la delimitación competencial con las CCAA). Ciertamente, hablar, por ejemplo, de la Justicia o de la Seguridad como servicio público pretende remarcar la exclusividad de su ejercicio por un poder público; aunque la expresión no nos parece convincente. Incluso el propio Tribunal Constitucional se ha referido a la Policía como un servicio público para la comunidad en su Sentencia señera en este ámbito: la 55/1990, de 28 de marzo. Pero, adviértase que cuando el Tribunal Constitucional realiza esta afirmación está aludiendo al artículo 12 de la Declaración de Derechos del Hombre y del Ciudadano, que, como vimos en la primera parte de esta trabajo, se refería «textualmente» a que «La garantía de los derechos del hombre

${ }^{63}$ Fernandez Segado, F. (1998), «Comentario al Artículo 104», en Comentarios a la Constitución, Alzaga Villaamil, O. (dir.), tomo VIII, Edersa, Madrid, p. 453.

${ }^{64}$ Así Fernandez Segado cuando expresa «Si la Policía es un servicio público ordenado a la colectividad social y a los valores que la misma se ha dado, es evidente que esta idea servicial, que impregna constitucionalmente a la Administración Pública, la aparta, a la Administración como estructura y al personal a su servicio, de la consecución de móviles particulares ajenos al interés general. Y ello tiene una especialísima trascendencia en el caso de las Fuerzas policiales, pues a través de ellas la Administración hace un uso institucionalizado de la coacción jurídica», ob. cit., p. 478. El autor está vinculando la idea de servicio público con interés general. 
$y$ del ciudadano necesita de una fuerza pública...». Sin embargo, el Tribunal literalmente afirma:

«De la Constitución se deduce que las Fuerzas de Policía están al servicio de la comunidad para garantizar al ciudadano el libre y pacifico ejercicio de los derechos que la Constitución y la Ley les reconocen, y este es el sentido del art. 104.1 C.E. que puede considerarse directamente heredero del art. 12 de la Declaración de Derechos del Hombre y del Ciudadano, configurando a la Policía como un servicio público para la comunidad».

Se produce entonces una identificación entre fuerza pública y servicio público que requiere esclarecerse, ya que las consecuencias que tiene anudadas esta noción son importantes.

\subsection{El sentido del servicio público}

La construcción jurídica del servicio público es de origen francés; esbozándose primero en el arrêt BLANCO por el Tribunal de Conflictos (1873), y consolidándose después por el Consejo Constitucional en el arrèt TERRIER (1903). En sus inicios, la doctrina del servicio público pretende afirmar la responsabilidad de la Administración ante la jurisdicción administrativa por los daños causados a particulares por aquellas actuaciones de personas que actuaban en nombre del Estado en el ejercicio de un servicio público. El Consejo Constitucional, afirmaba, bajo la influencia de Hauriou, que en estos casos no podía dirimirse dicha responsabilidad aplicando el Código civil.

Pese a las diversas posiciones, mayoritariamente se admite que el servicio público fue una doctrina trazada por Hauriou, quien lo conceptuó como un «servicio técnico prestado al público de forma regular y continua para la satisfacción de una necesidad pública por una organización no lucrativa, pudiendo gestionarse bien por la Administración Pública, bien por un concesionario» ${ }^{65}$. Sin embargo, más tarde, él mismo se convirtió en objetor de dicha construcción.

La doctrina se forjó, entonces, por León Duguit, quien la completó y la convirtió en piedra angular del Derecho administrativo ${ }^{66}$. Duguit distinguía dos funciones en el Estado: las que son de mando (imperio); y las que impli-

${ }^{65} \mathrm{El}$ estudio de este tema lo desarrollan con mayor profundidad los autores en cuyas obras nos hemos basado y cuyas citas aparecen detalladas a los largo de este punto; especialmente, MuÑoz Machado, S., Servicio público y mercado, Civitas, Madrid, 1998, p. 103 y ss.

${ }^{66}$ Martin Rebollo, L., «De nuevo sobre el Servicio Público: planteamientos ideológicos y funcionalidad técnica», en Revista de Administración Pública, núms. 100102/1983, p. 7. 
can la realización de unos servicios públicos (correos, telégrafos, ferrocarriles, etc), en las que la función del Estado no es mandar, sino servir. Para Duguit el concepto de soberanía es reemplazado por el de servicio público, utilizando esta expresión como «anti autoritaria»; contraponiendo la noción de servicio público a la del poder público, ya que el papel del Estado se justificará, no por su poder, sino por la finalidad de la realización de actividades que sean de interés general indispensables para la vida colectiva. Que el servicio público sea un principio de limitación del Estado se explica por la obligación de cumplir unos determinados fines; lo que legitima el poder del Estado para Duguit es, pues, la prestación de servicios públicos; calificándolos, en suma, como una actividad de interés general satisfecha, de un modo regular y continuo por la Administración, a través de un procedimiento especial ${ }^{67}$.

Ciertamente, el servicio público es una construcción con un contenido ideológico marcado, ya que ha constituido «una técnica instrumental que, como categoría histórica, traduce una dialéctica entre Estado y sociedad $\rangle^{6}$, confrontando lo público con lo privado. Concretándose en una técnica administrativa por la que servicios que antaño pertenecían a la iniciativa privada, son asumidos por el Estado sujetándolos al Derecho Público mediante la técnica del Servicio público ${ }^{69}$.

La noción del servicio público ha sufrido oscilaciones; incluso se ha hablado de su «muerte», entendido como instrumento esencial del Estado benefactor $^{70}$. Sin embargo, puede advertirse, incluso en nuestro texto constitucional, la continuidad de esta concreta técnica de actividad administrativa, adaptada a las transformaciones que ha ido experimentando el Estado, identificándose con la idea de solidaridad propia del Estado Social de Derecho.

Desde esta perspectiva, si bien es cierto que no puede hablarse de una noción unitaria del servicio público, y que hoy en día no puede entenderse

${ }^{67}$ Vid. Martin Rebollo, L., «De nuevo sobre el Servicio Público, ob. cit., p. 56

${ }^{68}$ CASSAgNe, J.C., «El resurgimiento del servicio público y su adaptación en los sistemas de economía de mercado (hacia una nueva concepción), en Revista de Administración Pública, núm. 140/1996, pp. 3-4.

69 Vid. Martín Rebollo, L., ob. cit. p. 11 y ss.

70 ArIÑo OrTIZ, G., «El servicio público como alternativa», en Revista Española de Derecho Administrativo, núm. 23/1979. Un tratamiento detallado de la crisis del concepto de servicio público lo hace ChInchilla MARIN, C., »Servicio Público: ¿crisis o renovación?, en Cuadernos de derecho judicial, núm. 28/1996, pp. 59-98. Manteniendo que, si bien conceptualmente la noción de servicio público está en descomposición, sin embargo, desde la perspectiva funcional de la sociedad actual es una noción en recomposición, al aparecer, en muchos casos, como un instrumento idóneo para hacer realidad el ideal de solidaridad y cohesión social que define el Estado. Esta es la posición mantenida también por Martin Rebollo, L. y Fernandez, T.R., quién reivindica el mantenimiento de la noción de servicio público para asegurar la indispensable solidaridad social que el mercado por si sólo no puede garantizar, p. 1. 
aisladamente, abstraída de las normas comunitarias, pervive la característica del servicio público, como una categoría diferenciada; como un título habilitante de potestades administrativas, o la justificación de la acción del poder público $^{71}$. En este sentido, Garrido Falla lo definió como prestaciones técnicas (transporte, educación, servicios sanitarios), que se prestan al público en general, de manera regular y continua, siendo de titularidad pública, aunque el servicio se preste en régimen de concesión administrativa, y bajo un régimen jurídico especial ${ }^{72}$.

La Constitución española de 1978 asume la noción de servicio público como prestación en diversos preceptos (art. 41: seguridad social; art. 28.2 servicios mínimos en caso de huelga; art. 43: protección de la salud; art. 50: servicios sociales). Pero, singularmente, es el artículo 128.2 el que establece, el contenido mínimo ${ }^{73}$ de los servicios públicos, ya que dicho precepto permite la iniciativa pública en la actividad económica, pudiendo reservarse mediante ley al sector público recursos o servicios esenciales.

De la configuración constitucional podemos concluir que el servicio público:

1. Supone una asunción de la titularidad de un servicio por el Estado.

2. Requiere publicatio, que implica la atribución mediante ley de la actividad privada al poder público.

3. Ha de tratarse de recursos o servicios esenciales, que satisfagan necesidades públicas.

4. La asunción de la titularidad del servicio por parte del Estado no implica necesariamente que lo gestione él, sino que puede atribuirse a los particulares, aunque sujetando dicha gestión a una serie de condiciones; esto es, lo que hace es impedir su desarrollo en régimen de libre iniciativa privada; pero no la elimina ${ }^{74}$.

En consecuencia, como advierte Muñoz Machado ${ }^{75}$, los servicios públicos no funcionan todos sometidos al mismo régimen jurídico, sino que algu-

71 MeILAN GiL, J.L., «El servicio público en el derecho actual», en Anuario da Facultade de Dereito da Universidade da Coruña, núm.1/1997, p. 371.

VALERO TORRIJOS, J., «El concepto de servicio público a la luz de la Constitución», http://www.carm.es/chac/interleg/arti0001.htm (última consulta, 5 mayo 2014): habla de una actividad reservada a la titularidad pública, conectando la declaración de servicio público con una actividad que ha de ser esencial, siendo ésta declaración una facultad del legislador.

72 Garrido Falla, F., «El concepto de servicio público en derecho español», en $R e$ vista de Administración Pública, núm. 135/1994, pp. 11 y 12.

${ }^{73}$ Chinchilla Marin, C., «Servicio Público: ¿crisis o renovación?», ob. cit.

${ }^{74}$ Idem.

75 Muñoz Machado, S., Servicio público y mercado, Civitas, Madrid, 1998, pp. $27-$ 115. Posición mantenida por la mayoría de la doctrina: ARIÑo OrTIZ, MARTín REBOLLO, 
nos lo hacen sujetos a un régimen de Derecho público y otros de Derecho privado; pues la Constitución no exige un régimen determinado, ni sobre la exclusividad de la Administración Pública, ni sobre las formas de colaboración de los privados en su gestión, pudiendo ser diversas las formas de participación de los particulares.

En síntesis, la noción del servicio público implica la asunción de una actividad del sector privado por parte del público, en atención a su consideración de servicio esencial, quedando sujeta a un régimen especial. Ejemplos claros de servicios públicos han sido y son los servicios de correos, teléfonos, electricidad, televisión, entre otros.

\subsection{La función del Estado}

Pero la noción de servicio público es diferente de la de función pública (entendida como función del Estado). En efecto, como advertía Zanobini, el concepto de servicio público se limita a algunos aspectos de la actividad administrativa; por el contrario la función pública es ejercicio de potestad pública, consecuencia de la soberanía del Estado ${ }^{76}$. La garantía de la seguridad ciudadana nunca se ha correspondido con la noción de servicio público, sino que ha sido siempre una función vinculada a la existencia misma del Estado, y por tanto, su acción reservada al poder público. Y es que como hemos visto en la primera parte de este trabajo, la asunción de la garantía de la seguridad por el poder público es una de las notas determinantes del nacimiento del Estado como organización política.

No puede hablarse de la seguridad ciudadana como servicio público, pues hablar de servicio público implica la prestación de una actividad que, en principio, no es ni pública ni administrativa; se convierte en pública mediante la publicatio, esto es cuando el legislador la reserva para sí. Por el contrario, la seguridad ciudadana está reservada, constitucionalmente, en exclusiva a la Administración Pública, ya que es una función de soberanía ${ }^{77}$. En consecuencia, no existirá la posibilidad de encomendar su gestión a agentes externos, de los que puede predicarse su colaboración, pero no la asunción de las funciones que el texto constitucional encomienda en exclusiva a las Fuerzas y Cuerpos de Seguridad.

La seguridad ciudadana como función del Estado se confirma, desde bien temprano, por el Tribunal de Justicia de Luxemburgo, al excluir los servicios

Chinchilla, Meilán Gil, frente a la concepción de Villar Palasí que entendía el servicio público como responsabilidad exclusiva de la Administración.

${ }^{76}$ Garrido Falla, F., «El concepto de servicio público en derecho español», en $R e$ vista de Administración Pública, núm. 135/1994., p. 4

77 Troncoso Reigada, A., «Dogmática administrativa y Derecho Constitucional: el caso del servicio público», Revista Española de Derecho Constitucional, núm. 57/1999, p. 101. 
de autoridad de las reglas de mercado. Claro exponente es desde la Sentencia Reyners, de 21 de junio de 1974, en la que el Consejo de Estado belga solicitaba, entre otras cuestiones, que el Tribunal se pronunciara acerca del significado de la expresión de actividades que suponen «ejercicio del poder público» ${ }^{78}$.

En primer lugar, en relación con la excepción a la libertad de establecimiento respecto prevista en el Tratado CEE de las actividades relacionadas con el ejercicio del poder público, considera que debe entenderse una excepción a la regla fundamental de la libertad de establecimiento; aunque dicha debe limitarse a lo estrictamente necesario para salvaguardar los intereses cuya protección les está permitida a los Estados miembros ${ }^{79}$. Por tanto, entiende el Tribunal que hay un interés legítimo de los estados miembros de reservar a sus propios nacionales un conjunto de empleos relacionados con el ejercicio del poder publico y la salvaguardia de los intereses nacionales ${ }^{80}$.

La seguridad ciudadana, entendida como un bien jurídico de ámbito colectivo, no individual, es una función propia del Estado ${ }^{81}$, derivándose de ello que su garantía corresponde, a los poderes públicos. En consonancia con su configuración como una de las funciones «indispensable del Estado» ${ }^{82}$, nuestro texto constitucional, en concordancia con ello, atribuye, cabalmente, a la Fuerzas y Cuerpos de Seguridad la función de proteger el libre ejercicio de los derechos y libertades y garantizar la seguridad ciudadana. Esta ordenación constitucional reafirma la seguridad ciudadana, como afirma Parejo, como «responsabilidad, objetivo y resultado de la acción del poder público, concretamente del administrativo» ${ }^{83}$.

${ }^{78}$ que se contemplaba en el art. 56.1 del Tratado CE.

79 Doctrina que ha reiterado ya en múltiples ocasiones: sentencias Comisión/Grecia, antes citada, apartado 7; Comisión/España, antes citada, apartado 34; de 30 de marzo de 2006, Servizi Ausiliari Dottori Commercialisti, C-451/03, Rec. p. I-2941, apartado 45; de 29 de noviembre de 2007, Comisión/Austria, C-393/05, Rec. p. I-10195, apartado 35, y Comisión/Alemania, C-404/05, Rec. p. I-10239, apartados 37 y 46, así como Comisión/ Portugal, antes citada, apartado 34).

80 Sentencias de 17 de febrero de 1980, Comisión c. Bélgica 149/1979; 22 de noviembre de 1995 caso Ioannis Vogugioukas c. IKA, C-443/Thijssen, apartado 8; Comisión/ España, apartado 35; Servizi Ausiliari Dottori Commercialisti, apartado 46; Comisión/ Alemania, apartado 38, y Comisión/Portugal, apartado 36). Sentencia de 30 de septiembre de 2003, Colegio de Oficiales de la Marina Mercante Española (C-405/01, Rec. p. I-10391); Sentencia de 29 de abril de 2010; Sentencia (Gran Sala), de 24 de mayo de 2011. Vid. con mayor detalle, MANGAS MARTín, A., Carta de los derechos fundamentales de la Unión Europea: comentario artículo por artículo, Fundación BBVA, 2008, p. 407.

${ }^{81}$ STC 325/1994, de 12 de diciembre.

${ }^{82}$ Lozano Serrano, C., «Art. 158.1 CE: límites al recorte y copago de servicios fundamentales», en Malvarez Pacual, L. y Ramirez Gómez, S.: (Drs.) Fiscalidad en tiempos de crisis, Aranzadi, Navarra, 2014, pp. 181-182.

${ }_{83}$ Parejo Alfonso, L., Seguridad pública y policía administrativa de seguridad, Tirant lo Blanch, Valencia, 2008, p. 31. 
La ubicación del artículo 104 en el Título IV (Gobierno y Administración) es determinante en la atribución funcional de la seguridad ciudadana a las Fuerzas y Cuerpos, que, además, se incluyen dentro de la Administración. De ello se desprenden varias consecuencias: en primer lugar, encomendar la garantía de la seguridad a fuerzas integradas en la Administración, entraña la sujeción de éstas a todas las garantías que la Constitución reserva a la misma, tanto la sujeción a los postulados constitucionales, como las más específicas contenidas en el artículo 103, especialmente el sometimiento pleno a la ley y al Derecho ${ }^{84}$ Así lo confirma el propio Tribunal Constitucional cuando afirma que el estatuto funcionarial se erige en garantía adicional del ejercicio de las funciones policiales tuitivas ${ }^{85}$.

En segundo lugar, tal y como se deriva de la legislación de desarrollo ( $L O$ 2/1986, de 13 de marzo de Fuerzas y Cuerpos de Seguridad) en el ejercicio de sus funciones, los miembros de las Fuerzas y Cuerpos de Seguridad tendrán a todos los efectos legales el carácter de Agentes de la Autoridad (art. 7). Por tanto, la garantía de la seguridad, orgánica y funcionalmente, se encomienda a agentes públicos: agentes de la autoridad. Ello entraña que existe una especial sujeción de los agentes de la autoridad (públicos) hacia los postulados constitucionales; apareciendo ello, inexcusablemente, como una garantía en el ejercicio de unas funciones que llevan aparejada la coacción y el uso de la fuerza. De modo que, admitiendo el hondo calado de las funciones que se encuadran dentro de los que es la garantía de la seguridad ciudadana, por su especial incidencia sobre derechos fundamentales y libertades públicas, constituye una exigencia constitucional revestirlas de las máximas garantías; requiriéndose la asunción de dichas funciones por fuerzas públicas de seguridad, por su especial vinculación a los mandatos constitucionales.

En efecto, la especial vinculación que para los poderes públicos predica el artículo 53.1 Ce respecto de los derechos fundamentales y las libertades públicas es una garantía que ha de cubrir la actuación policial en todos sus ámbitos. Y es esto, en definitiva, lo que trata de asegurar el art. 104.1 C.E.: la adaptación del sistema policial, de sus funciones y de sus principios básicos al orden constitucional, derivándose de ello una protección adecuada del ciudadano frente al peligro de eventuales extralimitaciones, lo que incluye también la posibilidad de acudir a la vía judicial para reaccionar frente a los

${ }^{84}$ La ubicación de las Fuerzas y Cuerpos de Seguridad en el seno de la Administración Pública implica «la sumisión de toda su actividad a los controles jurídicos que la Constitución establece respecto de la actuación administrativa entera», BARCELONA LLOP, J., «Reflexiones constitucionales sobre el modelo policial español», Revista Española de Derecho Constitucional, núm. 48/1996, p.100.

${ }^{85}$ STC 175/2011, de 8 de noviembre de 2011. Vid. además, SANCHEz Ferriz, R., «Funcionarios públicos: su especial deber de protección y respeto a los derechos y libertades», Revista General del Derecho, núm. 632/1997, p. 5247 y ss. 
excesos y abusos, que las Fuerzas y Cuerpos de Seguridad en el uso, en principio legítimo, de la fuerza y de los medios de coacción ${ }^{86}$.

La legislación confirma estos mandatos constitucionales al reafirmar que en el ejercicio de sus funciones, las Fuerzas y Cuerpos de Seguridad del Estado tienen como misión proteger el libre ejercicio de los derechos y libertades y garantizar la seguridad ciudadana (Artículo 11.1 LO 2/1986, de 13 de marzo de Fuerzas y Cuerpos de Seguridad). Destacándose en la misma Ley los principios básicos de actuación de los miembros de las Fuerzas y Cuerpos de Seguridad. Además, nuestra justicia penal prevé tipos penales específicos para los agentes públicos que tienen como vienen a avalar la especial vinculación al ordenamiento y a la garantía de los derechos. En la misma dirección, la ordenación constitucional de las Fuerzas y Cuerpos de Seguridad y su legislación de desarrollo ha de completarse, igualmente, con los instrumentos internacionales a los que ya nos hemos referido: la Resolución 34/169, de 17 de diciembre de 1979, de la Asamblea General de Naciones Unidas, sobre Código de Conducta para funcionarios encargados de hacer cumplir la ley; así como la Resolución 690 de 1979, de la Asamblea Parlamentaria del Consejo de Europa, Declaración sobre la Policía.

Todo este entramado constitucional, que reserva las funciones esenciales de garantía de la seguridad ciudadana a las Fuerzas y Cuerpos de Seguridad, permite la colaboración y auxilio de agentes externos, tal y como se desprende de la legislación de desarrollo ${ }^{87}$. Pero, dicha colaboración no puede entrañar la asunción de aquellas funciones que, por afectar a los derechos fundamentales, quedan reservadas en exclusiva a Fuerzas y Cuerpos de Seguridad. Lo contrario desnaturalizaría los mandatos constitucionales, al permitir que agentes privados asumieran funciones que son propias y exclusivas del Estado; descartándose, igualmente, que la seguridad sea un servicio público cuya ejecución pueda encomendarse al sector privado.

\section{TITLE: Public Security as State Service.}

RESUMEN: Este trabajo se centra en uno de los temas medulares de la organización del Estado como es la garantía de la seguridad, y tiene como objeto reivindicar, al calor la reciente sacudida legislativa en materia, la función de la Seguridad ciudadana como una función pública a desarro-

${ }^{86}$ STC 55/1990, de 28 de marzo.

${ }^{87}$ LO Fuerzas y Cuerpos de Seguridad del Estado: Artículo 4 1. Todos tienen el deber de prestar a las Fuerzas y Cuerpos de Seguridad el auxilio necesario en la investigación y persecución de los delitos en los términos previstos legalmente. 2. Las personas y entidades que ejerzan funciones de vigilancia, seguridad o custodia referidas a personal y bienes o servicios de titularidad pública o privada tienen especial obligación de auxiliar o colaborar en todo momento con las Fuerzas y Cuerpos de Seguridad. 
llar por las Fuerzas y Cuerpos de Seguridad; en tanto que exigencia constitucional, presupuesto de la salvaguarda de los derechos fundamentales y de las libertades públicas.

PALABRAS CLAVE: seguridad ciudadana, derechos fundamentales, función del Estado, Fuerzas Cuerpos de Seguridad.

ABSTRACT: This paper focuses on one of the core issues of the state organization: the guarantee of security. Our aim is to vindicate, taking into account the recent legislative shake in this field, the role of citizen security as a public service to be developed by the Security Forces; as constitutional requirement, and an essential element for safeguarding fundamental rights and public freedoms.

KEYWORDS: citizen security, public security, fundamental rights, State Service, Security Forces.

RECIBIDO: 19.05 .2014

ACEPTADO: 26.11.2014 